\title{
The Role of Ciliwung Condet Community in Fostering Ecological Intelligence in Urban Communities
}

\author{
Amin \\ FKIP UNISMA BEKASI \\ Corresponding email: aminunisma@gmail.com
}

\begin{abstract}
This study entitled The Role Ciliwung Condet Community in Fostering Ecological Intelligence in Urban Communities aims to determine the kinds of community activities to build ecological intelligence by community Condet Ciliwung and also its impact on public awareness in preserving the function of the environment. The research approach is qualitative method by using grounded research. Subjects of the study were 8 (eight) people consisting of 3 (three) members of Ciliwung Condet Community and 5 (five) people from the surrounding community who act as informants either as public figure as an informant base. The data collection technique is to conduct in-depth interviews using interview guide and looking the documentation. Data analysis is the process of systematically tracking and setting of interview transcripts, field notes and other materials collected to enhance the understanding of the material to be presented to the others. Based on data, it shows that Ciliwung Condet Community gives instrumental in growing ecological intelligence. Those activities include education and discussion about Ciliwung and conduct Ciliwung's action program in the form of plant breeding, travel Ciliwung themed festival held and its environment. However, the involvement of local community still smaller and more widely followed by people from Condet outsider.
\end{abstract}

Keywords-Ecological intelligence, ciliwung condet community and urban communities

\section{INTRODUCTION}

Ciliwung River is one of the main river which led into the Gulf of Jakarta with a total watershed area of $347 \mathrm{~km}^{2}$ and 117 $\mathrm{km}$ long main river (Pawitan, 2002). The area is crossed by rivers covers an area of Bogor Regency, Bogor, Depok City and Jakarta. Headwaters are located in the plateau which is located at Gunung Gede-Pangrango West Java (Nikmah, 2010).

One of the environmental problems in the Ciliwung River is the river water pollution with pollution index figures for the category of heavily polluted in the number $88 \%$ in 2011 to $32 \%$ in 2014 (BPLHD Jakarta, 2015). This is due to waste disposal of industrial waste, domestic or farms directly into river without being processed first. It shows a lack of public awareness of the importance of the benefit stream for their life

Condet region is a part of District Kramat Jati, the total area is 594 ha covers 3 villages, which are Bale Kambang, Kampung Batu Ampar and Central stretches from Jl. Jl Dewi Sartika until translucent. Simatupang. Condet is the old settlement which is a variety of fruit plantations stretching quality. Therefore, Condet used simultaneously reserves cultural fruits by the government. However, along with the number of people who are not accompanied by adequate environmental awareness, the environment in the region increasingly threatened Condet. These conditions encourage the inception of Ciliwung Condet Community with the goal to build an ecological intelligence surrounding.

Ciliwung Condet Community stands because of a man named Abdul Kodir who concerns about the changes of land uses and a devastating flood that destroyed farmers' fields Condet. His aims are to save the remnants of biodiversity and preserving ecosystems typical Condet Ciliwung. The term refers to a community social groups of organisms that has a same interest in caring environment. Ciliwung Condet Community established since June 21, 2004, chaired by Abdul Kodir made up of volunteers, students and scholars, business groups, local residents, and participants of other citizens who care about the environment and social culture that exists around Condet on riverbank Ciliwung precisely on J1 Munggang No. 06 RT. 10 RW.04 Ex Balekambang, Kramat Jati.

Ciliwung Condet Community has a role in improving ecological urban communities, especially around the river Ciliwung domiciled in Condet. Intelligence ecological (ecological intelligence) is the understanding and interpretation of human relationships with all elements along with other living beings (Goleman, 2009). Intelligent human being ecologically established itself as a control of the environment. Ecological intelligence as a deep empathy and concern for the environment, as well as how to think critically about what is happening in the environment as a result of our treatment (Jung, 2010 in Ramli, 2012). Ecological intelligence manifested in a real attitude and behavior that considers ecological capacity, and delivery loyal attitude of human nature (Hultkrantz, in Sternberg, 2004).

Ecological intelligence increased by strengthening the sustainable development paradigm. This concept requires the implementation of a cultural movement, the movement to build awareness of environmental preservation since the level of small-scale family and then widened to a larger scale such as the people. The consciousness is the result of a way of thinking group of people, each mind apart from one another (Simorangkir, 1987). According to Soekanto (1990), there are four indicators of awareness that each is a stage for the next stage and pointed to the level of awareness of certain ranging 
from the lowest to the highest, among other things: knowledge, understanding, attitudes, patterns of behavior (actions).

Humans who have ecological intelligence will have or apply ethics to the environment. According to Keraf (2001), there are nine principles of environmental ethics to be applied in the construction, namely (1) respect for nature (respect for nature), (2) is responsible for nature (responsibility for nature), (3) solidarity cosmic (cosmic solidarity), (4) to care for nature (carrying for nature), (5) no harm (no harm), (6) live in harmony with nature (living harmony with nature), (7) justice, (8) democracy, (9) moral integrity.

Ecological intelligence can be nurtured and improved through environmental education both formal and non-formal. In the environmental education, mental concept of man as a conqueror of nature needs to be changed into a man as part of nature (Neoloka, 2008). This has encouraged research to see how the role of the Ciliwung Condet Community in building ecological intelligence, especially urban communities in the surrounding area. The focus of the research is directed to answer the research question how the kinds of community activities develop ecological intelligence community Condet Ciliwung; and the impact caused by these activities on public awareness in preserving the function of the environment.

\section{METHOD}

This research uses descriptive qualitative method. Bogdan and Taylor (Maleong, 2011) states that qualitative methods as a research procedure that produces descriptive data in the form of words written or spoken of people and behaviors that can be observed. Djam'an Satori (2011) reveals that qualitative research is done because researchers wanted to explore phenomena that can't be quantified, descriptive such a process work step, a prescription formula, notions of a concept that is varied, the characteristics of goods and services, paintings, styles, manners of a culture, a physical model of an artifact, and so forth.

Research sites is in Balekambang District, Kramat Jati. The research subject is Condet Ciliwung community which is the key informants. Subject selection is done by selecting three (3) members of the Ciliwung Condet Community and 5 (five) of the surrounding community as an informan. Whereas the data collection techniques use conduct in-depth interviews using guide interview and looking the documentation to find data or variables such as notes, transcripts, books, newspapers, magazines, inscriptions, minutes of meetings, legger, agenda and so forth. This documentation is used to supplement the data obtained from interviews and observations, this source consists of documents and records.

Data analysis is the process of systematically tracking and setting of interview transcripts, field notes and other materials collected to enhance the understanding of the material to be presented to the others. Data analysis is the process of organizing and sorting data into patterns, categories and unit basic description so you can find the theme and can be formulated working hypotheses as suggested by the data." The analysis observed by studying all data from various sources after the data reduction with a summary core, the next step in preparing the units are then categorized in the same group, then checks the validity of the data and the last stage is concluded.

\section{FINDING AND DISCUSSIONS}

Based on interviews with informants member Ciliwung Condet Community or the surrounding community, data showed that the Ciliwung Condet Community attempt to return society to the culture of farming communities, farming typical fruits Condet like Salak. Empowerment is done by building intelligence in the form of ecological knowledge and understanding of the environment ranging from small children up to the parents or the community. However, there is little difference information between members of Ciliwung Condet Community and the surrounding community.

According to the Ciliwung Condet Community informant, Communities give knowledge of the environment to the public as follows: First, the Ciliwung that travel down the river and explore the history that is in Ciliwung. Activities are undertaken in the form of identifying the diversity of flora and fauna that still exist around the Ciliwung, observe the location of the damaged and broken threatened; Secondly, the School of Natural Ciliwung that are intended for children aged 7-12 year after year.The children are taught to love the environment in the form of presentations, film screenings, storytelling, educational games are held and provided the library; Third, education is the introduction of environmental tourism plays ranging from the provision of knowledge by learning and playing together in Ciliwung so that people concerned about the environmental and socio-cultural changes. Shape activities include camping, outbound, fairytale Ciliwung up ways to use the waste bin of plastic bottles; and Fourth, the program of action, which is a real form of environmental concern such as river clean-up, the introduction of farming barking and voluntary work

All the activities those mentioned above is done in the series of the Ciliwung day which held every 11th of November. On the anniversary of the Ciliwung, the activities carry out an integrated manner with other communities, such as the Community Ciliwung Bojong Gede, Depok, Bogor, blu bird, Astra, PKK, Scouts, students, school children, teens go green, sampoerna school of education, Greeners, Goerilaz.

Ciliwung Condet Community invites the community and also social media to follow the activities that is through a blog or web community and Ciliwung Condet Community Institute, Facebook, and Twitter. In addition, local government support is also quite good

Ciliwung Condet Community build coordination with other community in order to achieve the common goal of building ecological intelligence has much to do, they are: (1) Komunitas Rumpun Awi, the mission to save the bamboo; (2) Astra International which builds outbound for small children next to the river; and (3), Blu Bird as an Internet access provider. 
The positive impact of these activities is increasing public awareness of the environment but prosesntase increase is relatively small. This is due to the lack of volunteers, lack of public awareness that is close to basecamp Ciliwung Condet Community, there is no revenue flows steadily to Ciliwung Condet Community, school teachers Natural rely on volunteers while and usually only fill empty time, when they have to work it is no longer here because it is tied to the job.

Support from the government in all activities which are planned and conducted is still less of implements, merely just attended the even when invited. Government agency which relevant with the activities of Ciliwung Condet Community is the Regional Environmental Management Agency (BPLHD) also hasn't real cooperation. BPLHD which proclaimed Ecotourism program whose aim is to educate people to love the river until today hasn't seen the implementation.

Different opinions presented by informants from the local community or outside Ciliwung Condet Community. Society perceives that activities such as clean-up of the river, the river edge using a raft and inflatable boats, tree planting, nature school for children, and other events conducted by Ciliwung Condet Community actually good but not good in management. Surrounding communities are invited to participate in these activities, but its participation is relatively small and often do not follow all the action. More participants come from outside Condet.

Generally, the public looked its activities are good but the impact of its activities to raise public awareness about the environment is still less. The mindset of the community to be more concerned with the environment was not easy and can be quickly changed even assume that there is only useful activities carried out for the existence of Ciliwung Condet Community, wants to be known as an environmentalist and make money.

Ciliwung Condet Community continuously is trying to encourage people to become actively involved in environmental conservation. Although there are obstacles, such as community involvement is relatively small and it becomes a chore Ciliwung Condet Community to continue working to improve community involvement.

\section{CONCLUSIONS AND SUGGESTIONS}

Ciliwung Condet Community is a community based on the banks of the Ciliwung Condet, Balekambang. The location is included in the Cultural Heritage which maintains the original fruit Jakarta, barking Condet. Activities undertaken by the Ciliwung Condet Community include planting salak fruit, and environmental education for children. The carrying out various activities to preserve the Ciliwung and Betawi culture. From the start of education, nursery plants, up to the river and environmental advocacy. Various activities are packaged to attract the public.

Ciliwung Condet Community has improved ecological urban communities, especially around the river Ciliwung domiciled in Condet. Improving ecological intelligence is needed, because today is the attitude of society which is considered very abusive to the environment as disastrous for the environment. Floods, fires, landslides, the depletion of the ozone are some of the disaster caused by human actions being selfish by not thinking about the result of adverse ecological unbalance our own.

The development of public awareness of the environment is still relatively small. People who are around Ciliwung Condet Community is not enthusiastic to join the activities organized by Ciliwung Condet Community. This needs to be done further research what caused little public participation around the Ciliwung Condet Community activities.

\section{REFERENCES}

[1] Goleman, Daniel, 2009, "Ecological intelligence: how knowing the hidden impacts of what we buy can change everything," Broadway Bussines. New York.

[2] Jung, C.G, 2010, "Ecological Intelligence," available on https://jungianwork.wordpress.com/2010/02/10/onalchemy-c-g-jung-and-ecological-intelligence/

[3] Keraf. A, Sonny, 2010, "Etika lingkungan hidup," Jakarta: PT. Gramedia Media Nusantara.

[4] Nikmah. Siti Khoirun, 2010, "Pengabaian Pemerintah terhadap Eksistensi Penduduk Pinggir Sungai: Wajah Pengelolaan Sungai di Indonesia (Studi Sungai Ciliwung)," International NGO Forum on Indonesian Development (Infid), Jakarta.

[5] Pawitan. Hidayat, 2002, "Hidrologis DAS Ciliwung dan Andilnya terhadap Banjir Jakarta," Makalah disajikan dalam Lokakarya Pendekatan DAS dalam Menanggulangi Banjir Jakarta yang diselenggarakan oleh Lembaga Penelitian IPB bekerja sama dengan Andersen Consult, Jakarta, 2 Mei 2002.

[6] Ramli Utina, 2006, "Kecerdasan Ekologis Dalam Kearifan Lokal Masyarakat Bajo Desa Torosiaje Provinsi Gorontalo," disajikan pada Prosiding Konferensi dan Seminar Nasional Pusat Studi Lingkungan Hidup Indonesia Ke-21 13-15 September 2012 di Mataram, ISBN; 978-602-18848-0-5 (Halaman: 14 - 20).

[7] Satori Djam'an. Komariah Aan, 2011, "Metode Penelitian Kualitatif," Bandung: Alfabeta.

[8] Simorangkir,O,P, 1987, "Kesadaran Pikiran dan Tanggung Jawab," Jakarta: Yagrat.

[9] Soekanto, Soerjono, 2009, "Sosiologi Suatu Pengantar," Jakarta: Rajawali Pers.

[10] Sternberg, Robert J, (2004), "Handbook of Intelligence," Cambridge University Press, Cambridge. 